http://dx.doi.org/10.18778/1429-3730.40.05

\title{
Izabela Plesiewicz-Świerczyńska*
}

\section{OBECNOŚĆ FIRM JAPOŃSKICH W UNII EUROPEJSKIEJ}

\author{
THE PRESENCE OF JAPANESE COMPANIES IN EUROPEAN UNION
}

\begin{abstract}
This paper presents the main determinants of Japanese multinational companies location choice in European Union and especially in Poland. It presents the history of relations between the two trading partners. When choosing a location in the EU the Japanese take into account factors such as the availability and quality of human resources, market potential, the real cost of real estate, infrastructure and network, especially the concentration of industry. The availability of qualified personnel working in science and technology is among the chief factor location choices by Japanese companies. Non-manufacturing companies are attracted to industrially diversified regions with high income. Japanese companies investing in production projects actively utilize the benefits of the European single market.
\end{abstract}

Key words: European Union, Japan, Poland, company, economic development JEL classification: F23, F53

\section{Wstęp}

W ostatnich latach widoczna jest wielokierunkowa intensyfikacja relacji pomiędzy Japonią i Unią Europejską. Przyjęty w 2001 roku plan wzajemnej współpracy oprócz stosunków handlowych obejmuje również zagadnienia polityczne i kulturalne. Pomimo odmienności kulturowej widocznej nie tylko w języku, zachowaniu i hierarchiczności, Stary Kontynent stał się dla Japonii poważnym źródłem bezpośrednich inwestycji oraz największym beneficjentem japońskich inwestycji zagranicznych. Aktualnie większym nawet niż Chiny i Stany Zjednoczone Ameryki. W związku z olbrzymim znaczeniem Unii Europejskiej na politycznej arenie międzynarodowej, jej kontakty z krajami takimi jak Chiny czy USA obecnie rozwijają się coraz dynamiczniej, kładąc szczególnie nacisk na umowy sektorowe, w Łodzi.

* Mgr, asystent na Wydziale Japonistyki w Wyższej Szkole Studiów Międzynarodowych 
dialog polityczny czy też wymianę instytucjonalną. Najwiekszym partnerem handlowym Wspólnoty spoza Europy są Stany Zjednoczone, drugie miejsce zajmują Chiny przed Japonią.

Celem niniejszego artykułu jest zaprezentowanie obecności firm japońskich w Unii Europejskiej ze szczególnym omówieniem ich lokalizacji na terytorium Polski. Nakreślone zostanie tło historyczne nawiązania stosunków handlowych na linii Japonia - UE. Ukazane będzie znaczenie inwestycji japońskich w Europie, które wiążą się zarówno z transferem zaawansowanych technologii, zwiększeniem nakładów inwestycyjnych w różnych sektorach oraz z poprawą konkurencyjności produktów i technologii europejskich przedsiębiorstw. Przedstawione zostaną również firmy z japońskim kapitałem w Polsce.

Zagadnienie wzajemnych stosunków Unii Europejskiej i Japonii jest obecnie bardzo często poruszanym aspektem polityki międzynarodowej. Japońskie firmy w Europie są bardzo zróżnicowane w ich stylu prowadzenia działalności gospodarczej w zależności głównie od wielkości firmy i jej funkcji.

Wiele możliwości dla japońskich inwestycji w Unii Europejskiej stwarza również polityka rządu japońskiego w zakresie promocji inwestycji japońskich firm za granicą, w tym w krajach rozwiniętych. W ramach realizacji nowej strategii wzrostu gospodarczego rząd japoński zamierza zintensyfikować działania na rzecz promocji na rynkach zagranicznych japońskich technologii przyjaznych środowisku oraz technologii związanych z sektorem energetycznym i transportowym. Obecność japońskich firm w Unii Europejskiej, dzięki dyfuzji wiedzy i technologii wpływa korzystnie na proces przekształceń technologicznych oraz na wzrost konkurencyjności gospodarki różnych krajów. Ma również nieoceniony wpływ na zbliżenie ludzi i wzajemne poznanie nie tylko kultury korporacyjnej, ale i historii, bogatych tradycji, i upodobań.

\section{Zarys historii stosunków handlowych na linii Japonia - UE}

Do lat 90. XX wieku stosunki Unii Europejskiej z Japonią można określić raczej jako marginalne i monotematyczne. Dla Japonii funkcjonowanie Unii Europejskiej, a wcześniej Europejskiej Wspólnoty Gospodarczej ${ }^{1}$ było czymś niezrozumiałym i budziło w niej obawy. Integracja ekonomiczna i polityczna tej organizacji przez długi okres pozostawała dla niej niezgłębiona. Japończycy nie byli przekonani również co do przyszłości organizacji i determinacji krajów członkowskich do głębszej integracji. W szczególności środowisko biznesowe miało pełno obaw, iż w konsekwencji integracji państw nastąpi zamknięcie rynku europejskiego na towary z zewnątrz. W lutym 1978 roku, 20 lat po powstaniu EWG japoński

${ }^{1}$ Utworzonej 1 stycznia 1958 roku EWG; por.: W. Grabska, Koncepcja i praktyka integracji w EWG, Książka i Wiedza 1988. 
minister spraw zewnętrznych Ushiba Nobuhiko (jap. 牛場信彦, 1909-1984) tak wypowiadał się na temat Wspólnoty: „Jaki rodzaj uprawnień posiadają i za co odpowiadają naprawdę, wciąż nie mogę pojąć"2.

Korzystną zmianą, dzięki której możliwe było budowanie współpracy okazała się Deklaracja Haska ${ }^{3}$. Te fundamentalne zasady dialogu politycznego z 1991 roku przypieczętowały tworzenie wzajemnych relacji gospodarczych. Deklaracja miała w założeniach gromadzenie, porządkowanie oraz kodyfikację dotychczasowych osiągnięć w dziedzinie wzajemnych kontaktów Wspólnoty i Japonii. Zawarte w niej treści określiły status obu stron jako globalnych partnerów gospodarczych. Strony zobowiązały się poprzez tą deklarację do rozwoju struktur i promocji handlu międzynarodowego, a także zapewnienia równego dostępu do swoich rynków.

Traktat z Maastricht z 1992 roku, który ustanowił Unię Europejską ${ }^{4}$, przyczynił się do poszerzania zakresu tematycznego dialogu. Kompetencje przyznane przez ten dokument, jak również dążenie do stworzenia jednolitej polityki zagranicznej wzmocniły międzynarodową pozycję Unii Europejskiej i zacieśniły kontakty z Japonią. W międzyczasie pojawiało się jeszcze mnóstwo głosów nieufności ze strony japońskich polityków. Ishihara Shintarō (jap. 石原 慎太郎 ) twierdził w 1995 roku, że kwestia osiągnięcia głębszej integracji przez Unię Europejską jest wątpliwa: ,jeśli marzeniem jest przywrócenie potęgi europejskiej - zapomnijcie o nim. Bliższe spojrzenie na to, co jest nazywane 'Europą' odkrywa kulturowe i historyczne zróżnicowanie, które zablokuje całkowitą integrację. Powątpiewam aby kraje Europy, wywodzące się z różnych grup językowych, indywidualistyczne mogły przyjąć ponadnarodowe struktury i funkcjonować w ramach politycznej i ekonomicznej organizacji, wymagającej rezygnacji z narodowych interesów na rzecz wspólnych celów. [...] Próba wprowadzenia wspólnej waluty obrazuje problem. Paryż chce silnego franka, a Bonn marki”s. Podpisany dwa lata później, w 1997 roku Traktat Amsterdamski potwierdzał coraz większe znaczenie Unii, ujednolicał zewnętrzne oblicze i zapowiadał wzrost jej znaczenia dzięki akcesji kolejnych 10 państw6.

${ }^{2}$ http://psz.pl/117-polityka/percepcja-unii-europejskiej-w-japonii [dostęp: 20.10.2015].

${ }^{3}$ Konwencja znosząca wymóg legalizacji zagranicznych dokumentów urzędowych, sporządzona w Hadze dnia 5 października 1961 roku; por.: http://isap.sejm.gov.pl/DetailsServlet?id=W DU20051120938 [dostęp: 22.10.2015].

${ }^{4}$ Oficjalnie Traktat o Unii Europejskiej (fr. Traité sur l'Union européenne, ang. Treaty on European Union); http://oide.sejm.gov.pl/oide/images/files/dokumenty/traktaty/Traktat_amsterdamski_ PL_16.pdf [dostęp: 23.10.2015]. Zob. też. J. Ruszkowski, Ponadnarodowość w systemie politycznym Unii Europejskiej, Wolters Kluwer, Warszawa 2010; C. Kosikowski, Finanse i prawo finansowe Unii Europejskiej, Wolters Kluwer, Warszawa 2014.

5 Cyt. za: M. Mohamad, S. Ishihara, The Voice of Asia: Two Leaders Discuss the Coming Century, Kodansha International, Tokyo New York London 1995, s. 27-28.

${ }^{6}$ Oficjalna nazwa: Traktat z Amsterdamu zmieniajacy Traktat o Unii Europejskiej, Traktaty ustanawiające Wspólnoty Europejskie oraz niektóre związane z nimi akty. Wszedł w życie 1 maja 
Wprowadzenie wspólnej waluty oraz wycofanie z obiegu walut narodowych w większości państw Unii korzystnie wpłynęło na pogłębianie się integracji gospodarczej Wspólnoty i Japonii. Dodatkowo, dla polepszenia kontaktów bilateralnych uzgodniono system spotkań i konsultacji UE - Japonia. Jednym z nich jest coroczny Szczyt UE - Japonia, na którym podsumowywane są dotychczasowe osiągnięcia. Spotkania mają również na celu inicjowanie dalszej, coraz bardziej efektywnej współpracy.

Na ostatnim, 23. dwustronnym szczycie, który odbył się 29 maja 2015 roku, Unię Europejską reprezentowali przewodniczący Rady Europejskiej Donald Tusk oraz przewodniczący Komisji Europejskiej Jean-Claude Juncker, Japonię zaś - premier Abe Shinzō (jap. 安倍 晋三). Przewodniczący Rady Europejskiej podkreślał znaczenie wzajemnej współpracy: „Cenimy sobie przyjaźń z Japonią i nasze wspólne wartości. Jesteśmy zdecydowani kontynuować partnerstwo"7. Przywódcy podjęli decyzję o przyspieszeniu negocjacji nad umową o partnerstwie strategicznym oraz umową o wolnym handlu między UE a Japonią.

Dodatkowo UE i Japonia pokazały, iż łączą siły nie tylko odnośnie handlu, ale również na polu technologii, badań oraz innowacji ${ }^{8}$. Wzmacnianie partnerstwa gospodarczego związane jest z działaniem na rzecz liberalizacji rynków, znoszeniem barier dla handlu, rozwojem społeczeństwa informacyjnego i promocją inwestycji. Jak podkreślają Japończycy, Unia jest podawana za wzór do naśladowania w dziedzinie integracji i przykład udanej współpracy państw, które w przeszłości były uwikłane w konflikty.

\section{Współpraca handlowa i inwestycyjna Japonii z Unią Europejską}

Kraje Unii Europejskiej są trzecim po Chinach i USA partnerem handlowym Japonii, natomiast Japonia zajmuje szóste miejsce w obrotach UE z zagranicą. W 2011 roku wymiana handlowa na linii Japonia - UE wyniosła 145,2 mld USD z czego eksport towarów UE do Japonii wyniósł 86,7 mld USD, a import 65,8 mld USD $^{9}$. Poniższy wykres przedstawia wymianę handlową między Japonią a UE w latach 2000-2010 w mld euro.

1999 roku; https://polskawue.gov.pl/files/polska_w_ue/prawo/traktaty/Traktat_amsterdamski.pdf [dostęp: 22.10.2015].

${ }^{7} \mathrm{http}: / / w w w . c o n s i l i u m . e u r o p a . e u / p 1 / m e e t i n g s /$ international-summit/2015/05/29/ [dostęp: 24.10.2015].

${ }^{8}$ Unia Europejska i Japonia chcą razem pracować nad technologią 5G oraz nad badaniami i innowacjami. http://europa.eu/rapid/press-release_IP-15-5069_en.htm [dostęp: 24.10.2015].

${ }^{9}$ http://www.mg.gov.pl/Wspolpraca+z+zagranica/Wspolpraca+gospodarcza+Polski+z+kraj ami+wschodnimi+i+pozaeuropejskimi/Japonia.htm [dostęp: 20.10.2015]. 


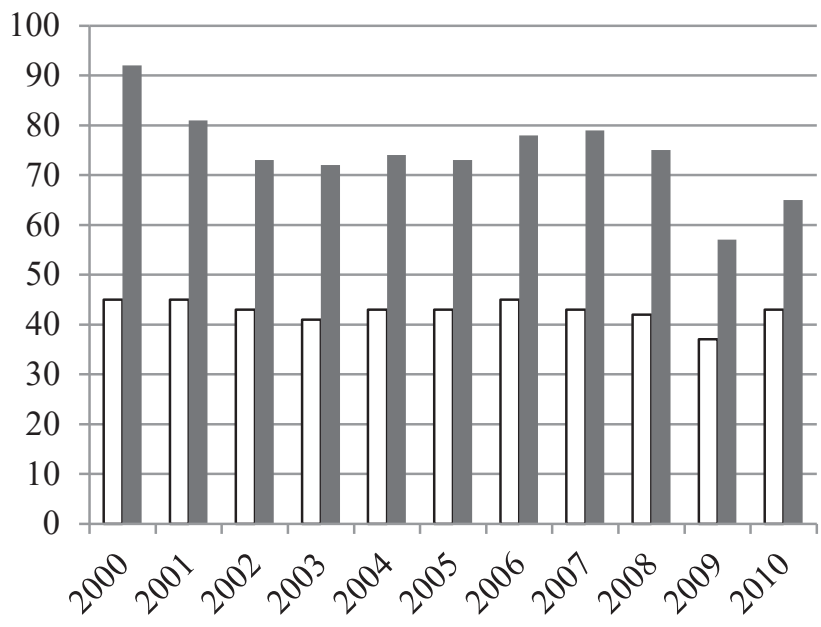

$\square$ EU27 eksport do Japonii - EU27 import do Japonii

Wykres 1. Wymiana handlowa między Japonią a Unią Europejską (w mld euro)

Źródlo: Eurostat http://www.iitrade.ac.in/kmarticle.php?topic=EU\%20and\%20Japan\%20to\%20 start\%20FTA\%20talks [dostęp: 12.10.2015].

Pierwsze japońskie fabryki zaczęły powstawać na terenie Europy na przełomie lat 60. i 70. XX wieku, kiedy Japonia przeżywała największy rozkwit gospodarczy czasów powojennych. Związane było to ze stopniową liberalizacją rynków oraz prosperity japońskiej ekonomii. Światowa wystawa Expo, która odbyła się w 1970 roku w Osace zaprezentowała Japonię jako lidera w produkcji m.in. statków, samochodów, telewizorów i odbiorników tranzystorowych i otworzyła przed nią nowe możliwości inwestowania na rynkach europejskich ${ }^{10}$.

Firma Sony rozpoczęła działalność na rynku europejskim już w 1959 roku w Zug (Szwajcaria) ${ }^{11}$. W 1961 roku Honda uruchomiła sprzedaż motocykli w Hamburgu'12, a w 1972 roku w Ostendzie (Belgia) rozpoczęła działalność firma Daikin - dostawca sprzętu do ogrzewania ${ }^{13}$. Hitachi, potentat w dziedzinie produkcji maszyn przemysłowych i podzespołów pojawił się w Europie w 1982 roku $^{14}$. Japończycy chętnie rozpoczynali także inwestycje w Wielkiej

${ }^{10}$ Wystawa stała się symbolem powojennego odrodzenia Japonii i początkiem wzrostu nowej siły gospodarczej; por.: Nihon Bankoku Hakurankai Kyōkai, Japan World Exposition, Osaka, 1970, Japan Association for the 1970 World Exposition, 1969.

${ }^{11} \mathrm{http}: / / w w w . s o n y-e u r o p e . c o m / a r t i c l e / i d / 1178278971660$ [dostęp: 16.05.2013].

${ }_{12}$ Por.: J. McDonough, K. Egolf, The Advertising Age Encyclopedia of Advertising, Routledge 2015, s. 811.

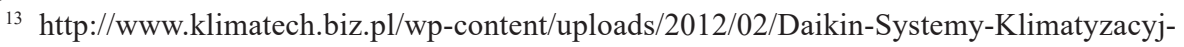
ne-2011.pdf [dostęp: 24.10.2015].

${ }^{14} \mathrm{http} / / / w w w . h i t a c h i . e u /$ en/about/hitachi/ [dostęp: 24.10.2015]. 
Brytanii ze względów językowych: angielski jest językiem, którym najczęściej posługują się w kontaktach biznesowych.

Panasonic Corporation wytwarza ekrany ciekłokrystaliczne w Republice Czeskiej. Firma Sharp ma zakłady w Polsce, a Sony jest zlokalizowana m.in. na Słowacji, w Austrii, Hiszpanii i Francji. Ponadto Sony, jeden z największych światowych producentów elektroniki użytkowej istnieje w technologii telefonów komórkowych niemalże w całej Europie.

Japońskie firmy biotechnologiczne na Starym Kontynencie mieszczą się m.in. w Anglii i we Francji. Ebara Corporation, przedsiębiorstwo alternatywnych rozwiązań energetycznych, prowadzi działalność we Włoszech, Niemczech, Szwajcarii, Wielkiej Brytanii oraz w Polsce ${ }^{15}$. To międzynarodowe przedsiębiorstwo o obrotach ponad 3,5 miliarda euro jest jednym z największych wytwórców pomp na świecie ${ }^{16}$. Ostatnio producent wiązek elektrycznych, firma Sumitomo przeniosła swój zakład produkcyjny z Polski do Rumunii, gdzie jest tańsza siła robocza.

Analizując europejskie regiony, w których ulokowany jest japoński przemysł, można stwierdzić, że skupia się on w wielkich okręgach miejskich. Są to przede wszystkim: Londyn (Wielka Brytania), Île-de-France (Francja), Düsseldorf i Darmstadt (Niemcy), Noord - Holland (Holandia), Lombardia (Włochy), Cataluña (Hiszpania), a także Kozep-Magyarorszag (Węgry) ${ }^{17}$.

W Europie najlepiej rozwinął się japoński przemysł motoryzacyjny i maszynowy, jednak obecnie fala inwestycji japońskich nie ogranicza się tylko do samochodów i branż pokrewnych, takich jak części i podzespoły elektroniczne.

$\mathrm{Na}$ Starym Kontynencie zadomowiły się również firmy z branży spożywczej. Shoda Shoyu produkuje sos sojowy w Walii, a Ajinomoto, producent zupek instant - w Polsce. Wszystkie firmy zapowiadają zwiększenie produkcji w zakładach, by wykorzystać falę popytu. W 2004 roku odnotowano ponad 1300 firm z kapitałem japońskim w Europie które stworzyły około 200 tysięcy miejsc pracy. Obecnie na rynku europejskim zlokalizowanych jest ponad 3300 fabryk. Ocenia się, że inwestycje te stworzyły ponad 400 tysięcy miejsc pracy ${ }^{18}$. W tabeli 1 przedstawiono 30 największych japońskich firm produkcyjnych w Europie wraz z liczbą zatrudnionych.

${ }^{15} \mathrm{http}: / /$ trade.ec.europa.eu/doclib/docs/2006/september/tradoc_113403.pdf [dostęp: 25.10.2015].

${ }^{16} \mathrm{http}: / / w w w . e b a r a . c o m . p 1 /[$ dostęp: 24.10.2015].

17 http://kamome.lib.ynu.ac.jp/dspace/bitstream/10131/6913/1/5Priede.pdf [dostęp: 24.10.2015].

${ }^{18}$ https://www.jetro.go.jp/poland/linki/firmy_pl.html [dostęp: 20.10.2015]. 
Tabela 1. Lista największych japońskich firm produkcyjnych w Europie wraz z liczbą zatrudnionych

\begin{tabular}{|c|c|c|c|c|}
\hline Miejsce & Firma & $\begin{array}{c}\text { Liczba } \\
\text { zatrudnionych }\end{array}$ & $\begin{array}{c}\text { \% w Europie } \\
\text { albo EMEA }\end{array}$ & $\begin{array}{l}\text { Zatrudnieni w Eu- } \\
\text { ropie lub EMEA }\end{array}$ \\
\hline 1 & Fujitsu & 173,000 & 18 & 31,000 \\
\hline 2 & Toyota & 333,498 & 6 & 20,051 \\
\hline 3 & Ricoh & 107,431 & 17 & 17,850 \\
\hline 4 & Canon & 197,000 & 8 & 16,000 \\
\hline 5 & Sony & 146,600 & 10 & 14,953 \\
\hline 6 & Nissan & 160,530 & 9 & 14,500 \\
\hline 7 & Asahi Glass & 54,000 & 10 & 14,200 \\
\hline 8 & Denso & 132,276 & 10 & 13,000 \\
\hline 9 & Bridgestone & 143,448 & 9 & 12,500 \\
\hline 10 & NSG & 29,300 & 40 & 11,700 \\
\hline 11 & Toshiba & 206,087 & 6 & 11,562 \\
\hline 12 & $\begin{array}{l}\text { Sumitomo } \\
\text { Electric Group }\end{array}$ & 206,323 & 6 & 11,500 \\
\hline 13 & Hitachi & 323,000 & 4 & 11,500 \\
\hline 14 & Panasonic & 293,742 & 4 & 10,500 \\
\hline 15 & Honda & 180,000 & 4 & 8,000 \\
\hline 16 & Takeda & 30,481 & 25 & 7,620 \\
\hline 17 & NTT Data & 61,000 & 10 & 6,000 \\
\hline 18 & NYK & 53,192 & 10 & 5,222 \\
\hline 19 & Fujifilm Holdings & 80,322 & 6 & 5,000 \\
\hline 20 & Olympus & 32,937 & 14 & 4,500 \\
\hline 21 & $\begin{array}{l}\text { Mitsubishi Chem- } \\
\text { ical Holding }\end{array}$ & 55,000 & 8 & 4,500 \\
\hline 22 & Astellas & 17,454 & 25 & 4,300 \\
\hline 23 & $\begin{array}{l}\text { Fast Retailing } \\
\text { (Uniqlo et al.) }\end{array}$ & 72,000 & 6 & 4,210 \\
\hline 24 & Komatsu & 47,208 & 8 & 3,763 \\
\hline 25 & Nomura & 27,956 & 13 & 3,618 \\
\hline 26 & Nidec & 100,394 & 3 & 2,981 \\
\hline 27 & Sharp & 50,644 & 5 & 2,674 \\
\hline 28 & Daiichi Sankyo & 32,000 & 8 & 2,500 \\
\hline 29 & Kao & 33,350 & 7 & 2,400 \\
\hline 30 & Seiko Epson & 73,639 & 3 & 2,153 \\
\hline SUMA & & 3453,812 & 10 & 280,257 \\
\hline
\end{tabular}

Źródło: http://rudlinconsulting.com/top-30-japanese-companies-in-europel [dostęp: 15.09.2015]. 
Większość produktów eksportowanych z Unii Europejskiej do Japonii zwolniona jest z ceł (ponad 60\% eksportu). Ograniczenie w większej eksploracji rynku japońskiego przez towary europejskie stanowią tutaj bariery pozataryfowe - zarówno te o charakterze regulacyjnym, jak i wynikające ze specyfiki rynku. Japończycy bardzo chętnie inwestują na rynkach europejskich nie tylko ze względu na niskie koszty produkcji, aby również ze względu na fakt uniknięcia ryzyka kursowego i chęci bycia konkurencyjnymi. Mieszkańcy Japonii biorą pod uwagę w miejscu planowanej lokalizacji również koszty kapitału oraz technologii, klimat inwestycyjny i stopień rozwoju infrastruktury. Wyszukują rejony dla swoich fabryk w pobliżu portów, autostrad czy lotnisk. Utrzymanie pozycji lidera w głównych sektorach produkcyjnych związane jest z posiadaniem możliwości produkcyjnych w Europie. Duże znaczenie mają tutaj uwarunkowania historyczne. W XIX wieku miało miejsce otwarcie Japonii na świat i kulturę europejską.

\section{Zarys historii dwustronnej współpracy gospodarczej między Japonią a Polską}

Za rozpoczęcie współpracy gospodarczej między Japonią a Polską można uznać podpisanie w 1978 roku podczas wizyty prezesa Rady Ministrów Piotra Jaroszewicza w Japonii tzw. Układu między PRL a Japonią o handlu i żegludze, Porozumienia między Rządem PRL a Rządem Japonii o współpracy kulturalnej oraz Umowy między Rządem PRL a Rządem Japonii o współpracy w dziedzinie nauki i techniki ${ }^{19}$. Następnie, w lutym 1980 roku podpisano w Tokio bilateralną umowę o unikaniu podwójnego opodatkowania w zakresie podatków i dochodów, a dziesięć lat później porozumienie między rządami obu państw dotyczące japońskiej pożyczki na fundusz stabilizacyjny w Polsce (w wysokości $150 \mathrm{mln}$ USD). W 1989 roku Japonia udzieliła Polsce pomocy żywnościowej w postaci dostawy mąki pszennej o wartości 25 mln dolarów. Dochód ze sprzedaży zasilił fundusz, dzięki któremu zrealizowano 39 projektów przyczyniających się do socjoekonomicznego rozwoju Polski ${ }^{20}$.

Począwszy od 1990 roku, Agencja Międzynarodowej Współpracy wspiera gospodarkę rynkową w Polsce poprzez pomoc w rządowych projektach związanych z finansami, przemysłem i handlem. W ramach współpracy technologicznej szkolenia w Japonii odbyły 784 osoby, a do Polski zostało oddelegowanych 287 ekspertów japońskich. Współpraca obejmowała wiele dziedzin, takich jak poprawa wydajności produkcji, zarządzanie jakością, oszczędzanie

19 http://www.mg.gov.pl/Wspolpraca+z+zagranica/Wspolpraca+gospodarcza+Polski+z+kraja $\mathrm{mi}+$ wschodnimi $+\mathrm{i}+$ pozaeuropejskimi/Japonia.htm?theme=mg [dostęp: 18.10.2015].

${ }^{20}$ http://www.pl.emb-japan.go.jp/relations/zarys_relacji.htm [dostęp: 18.10.2015]. 
energii, rozwój regionalny, prywatyzacja kolei czy szkolenie kadry informatycznej. Wartość udzielonej pomocy wyniosła 62 mln EUR ${ }^{21}$. W 2010 roku między Głównym Instytutem Górnictwa w Katowicach oraz Instytutem Chemicznej Przeróbki Węgla w Zabrzu, a japońską Agencją JCOAL odpowiedzialną za implementację polityki rządu Japonii w obszarze energii i technologii opartych na węglu podpisano umowę o współpracy w zakresie rozwoju technologii czystego węgla. ${ }^{22}$ Warto w tym miejscu także wspomnieć, że w kwietniu 2004 roku w Tokio rozpoczął działalność pierwszy Instytut UE. Rok później uruchomiono także Instytut UE w Kansai (EUIJ Kansai). Dzięki nim pracownicy naukowi oraz uczelnie europejskie, mają możliwość indywidualnych kontaktów oraz wymiany doświadczeń.

\section{Inwestycje japońskie w Polsce}

W 2004 roku na terenie Polski zlokalizowanych było 120 firm z kapitałem japońskim (uwzględniając firmy lokalne i przedstawicielstwa). W 2011 roku liczba ta wzrosła do 268 , z czego około 80 to firmy produkcyjne. W 2015 roku jest ich już powyżej 300. Inwestycje Japonii w Polsce na koniec 2010 roku osiągnęły 1,547 miliard mln USD (wg. JETRO). Według danych Ministerstwa Gospodarki obroty handlowe polsko - japońskie w 2011 roku wyniosły 3 mld euro, w tym nasz eksport 407,5 mln euro, a import 2,6 mld euro. Japońskie firmy zatrudniają ponad 30000 pracowników. Do 2007 roku skupiały się na inwestycjach w przemyśle samochodowym. Regionami, gdzie skupia się japoński przemysł są województwa: mazowieckie, kujawsko-pomorskie i dolnośląskie.

Dzięki inwestycjom firm takich jak: Sharp i Toshiba Polska jest określana mianem „kraju LCD”, który ma według inwestorów w przyszłości produkować większość ekranów LCD na Europę. Obecnie produkcja modułów LCD w Polsce pokrywa ponad $40 \%$ zapotrzebowania Unii Europejskiej na te produkty.

Firmy japońskie w Polsce skupiły się na produkcji głównie części samochodowych (Bridgestone), łożysk (NSK, Toho, Yagi) oraz wcześniej wspomnianych modułów do telewizorów LCD. Ostatnio obserwuje się rozwój takich sektorów jak: maszynowy (Suruga, Hitachi, Fanuc), elektroniczny (Funai, Panasonic, Sumika, Sharp, Toshiba), spożywczy (Ajinomoto), chemiczny (Asysta LifeScience Polska, Astellas Pharma, Sumi - Agro Poland).

${ }^{21}$ https://www.msz.gov.pl/resource/53fcacc6-f6d9-4448-a9dc-bc1f4908fbf7:JCR [dostęp: 20.10.2015].

${ }^{22} \mathrm{http} / /$ www.mg.gov.pl/Wspolpraca+z+zagranica/Wspolpraca+gospodarcza+Polski+z+kraja mi+wschodnimi $+\mathrm{i}+$ pozaeuropejskimi/Japonia.htm?theme=mg [dostęp: 20.10.2015]. 
Sektor motoryzacyjny skupiony jest głównie w województwie dolnośląskim, a sektor produkcji monitorów i telewizorów LCD zlokalizowany w województwie kujawsko-pomorskim. Do firm produkujących części samochodowe, które zlokalizowały swoje zakłady na terenie Polski należą m.in.: Toyota Motor (silniki Diesla, silniki spalinowe, skrzynie biegów), Isuzu Motors (silniki Diesla), Tokai Gomu (gumowe części antywibracyjne), Nihon Gaishi (DPF), Sanden (plastikowe kompresory do klimatyzatorów samochodowych), Bridgestone (opony). Moduły LCD produkowane są przez m.in. Toshiba, Sharp i Orion są przeznaczone głównie na eksport do Europy Zachodniej, dlatego też ich sprzedaż w znacznym stopniu przyczynia się do wzrostu polskiego eksportu ${ }^{23}$. Poniższy wykres przedstawia ilość japońskich inwestycji w Polsce w latach 1995-2010.

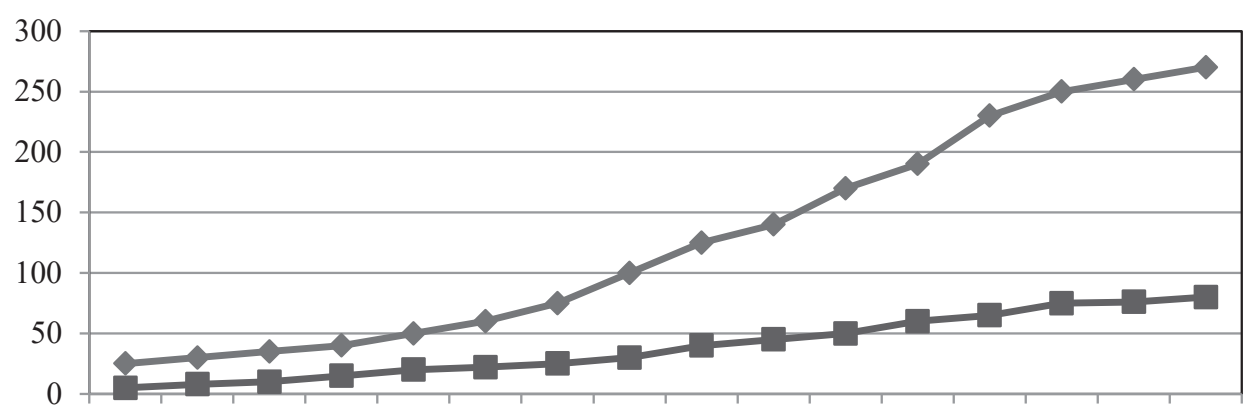

1995199619971998199920002001200220032004200520062007200820092010

—ilość firm ogółem $\quad$ - $\quad$ ilość inwestycji w sektorze produkcyjnym

Wykres 2. Ilość japońskich inwestycji w Polsce w latach 1995-2010

Źródto: JETRO www.jetro.go.jp/poland/linki/firmy.htm [dostęp: 20.10.2015].

W 2002 roku bank Mitsubishi Tokyo UFJ otworzył swoją filię (wówczas Tokyo Mitsubishi Bank), która obsługuje japońskie firmy na terenie Polski. Mnożą się również japońskie firmy logistyczne np. Frigo Logistics (Żnin koło Bydgoszczy), biura rachunkowe np. Centrum finansowo-rozliczeniowe Bridgestone (Poznań). Odnotowuje się także zainteresowanie japońskich firm realizacją projektów w sektorze energetycznym (JPOWER/Mitsui - Bussan, Hitachi) ${ }^{24}$. W 2010 roku koreańsko-japońska grupa LOTTE (produkcja słodyczy) dokonała zakupu firmy E. Wedel i w przyszłości planuje następne inwestycje w Polsce. Japończycy podjęli działania na rzecz inwestycji związanych

${ }^{23}$ www.jetro.go.jp/poland/linki/firmy.html [dostep: 20.10 .2015$]$.

${ }^{24} \mathrm{http}: / /$ www.mg.gov.pl/Wspolpraca+z+zagranica/Wspolpraca+gospodarcza+Polski+z+kraj ami+wschodnimi+i+pozaeuropejskimi/Japonia.htm [dostęp: 20.10.2015]. 
z poszukiwaniem gazu łupkowego (korporacja Mitsui \& Co odkupiła od spółki Maraton Oil 9\% udziałów w 10 koncesjach poszukiwawczych ${ }^{25}$. Duży ruch odnotowuje się również w branżach pozaprodukcyjnych.

W 2011 roku działało na terenie województwa łódzkiego 6 firm z kapitałem japońskim, w tym 5 zakładów produkcyjnych np. Fujitsu Technology Solutions Sp. z o.o.

Firmy te zatrudniały ponad 2000 pracowników i zainwestowały ponad 500 mln złotych.

Poniższa tabela prezentuje wymianę handlową między Japonią a Polską w mln euro od 2010 roku.

Tabela 2. Wymiana handlowa między Japonią a Polską (w mln EUR)

\begin{tabular}{|l|r|r|r|r|r|r|}
\cline { 2 - 7 } \multicolumn{1}{c|}{} & $\mathbf{2 0 1 0}$ & $\mathbf{2 0 1 1}$ & $\mathbf{2 0 1 2}$ & $\mathbf{2 0 1 3}$ & $\mathbf{2 0 1 4}$ & $\mathbf{2 0 1 5}$ (I-X) \\
\hline Obroty & 3075,4 & 3075,4 & 2658,7 & 2657,9 & 2852,9 & 2364,51 \\
\hline Eksport & 346,7 & 408,7 & 440,1 & 509,0 & 492,1 & 413,23 \\
\hline Import & 2728,6 & 2666,7 & 2218,6 & 2148,9 & 2360,8 & 1951,28 \\
\hline Saldo & $-2382,1$ & $-2258,0$ & $-1788,5$ & $-1639,9$ & $-1868,7$ & $-1538,05$ \\
\hline
\end{tabular}

Źródto: System Insigos, Ministerstwo Gospodarki http://www.msz.gov.pl/pl/polityka_zagraniczna/inne_kontynenty/azja_i_pacyfik/stosunki_dwustronne_azja_pacyfik/japonia?printMode-etrue [dostep: 10.11.2015].

Za najbardziej rozwojowe z punktu widzenia możliwości wzrostu inwestycji japońskich w Polsce uważa się inwestycje w następujących sektorach: energetycznym, rolno - spożywczym, finansowym oraz usługowym. Obserwuje się również rosnące zainteresowanie firm japońskich działaniami związanymi z szeroko rozumianą ochroną środowiska (energooszczędność, zarządzanie odpadami, recycling) oraz w sektorze transportowym. Polityka rządu japońskiego w zakresie promocji inwestycji japońskich firm za granicą zachęca do inwestowania w Polsce. Plany budowy elektrowni atomowej w Polsce, modernizacja polskich elektrowni konwencjonalnych, a także rozwój energii pochodzącej ze źródeł alternatywnych i technologii energooszczędnych stwarzają nowe możliwości współpracy z partnerami z Japonii. Poniższa mapa przedstawia główne japońskie firmy produkcyjne w Polsce.

${ }^{25}$ https://www.msz.gov.pl/resource/feec2fc6-b64d-4a16-8104-020f23765052:JCR [dostęp: 20.10.2015]. 


\section{Mapa japońskich firm produkcyjnych w Polsce opracowanie: Ambasada Japonii luty 2012}

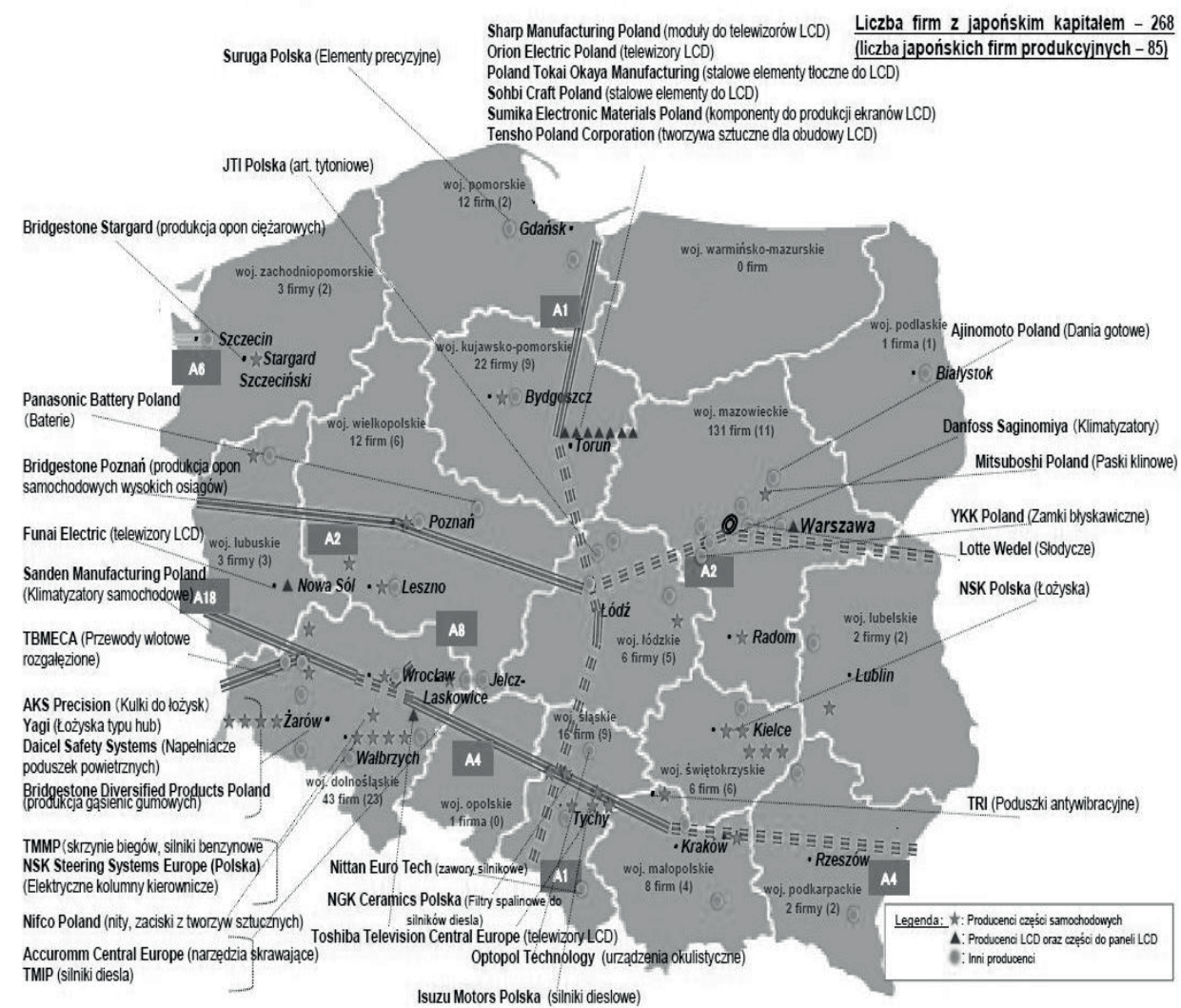

Rys 1. Główne japońskie firmy produkcyjne w Polsce

Źródlo: Ambasada Japonii w Polsce, http://www.pl.emb-japan.go.jp/keizai/documents/ kigyou_ chizu_pl.pdf [dostęp: 10.10.2015].

\section{Podsumowanie}

W ciągu ostatnich kilkunastu lat Unia Europejska znacznie zintensyfikowała swoje relacje z Japonią. Wzajemne stosunki opierają się na promowaniu pokoju i bezpieczeństwa, wzmacnianiu partnerstwa gospodarczego i handlowego. W najbliższej przyszłości UE i Japonia pragną poszerzać współpracę w dziedzinie technologii informacyjnych i komunikacyjnych, a w szczególności wzmocnić współpracę w kwestii multilateralizmu i spraw gospodarczych. Jednym z priorytetów jest także utworzenie strefy wolnego handlu w regionie Azji i Pacyfiku (Partnerstwo Transpacyficzne 
- TPP). Choć istotne bariery w nawiązywaniu kontaktów z Japonią mogą stanowić język i kultura, to nie są one uważane za niemożliwe do pokonania.

Dalsza współpraca UE - Japonia z pewnością będzie polegała na wzmacnianiu partnerstwa gospodarczego i handlowego, promowaniu pokoju i bezpieczeństwa oraz stawianiu czoła wyzwaniom globalnym i społecznym.

\section{Bibliografia}

Grabska W., Koncepcja i praktyka integracji w EWG, Książka i Wiedza 1988.

Kosikowski C., Finanse i prawo finansowe Unii Europejskiej, Wolters Kluwer, Warszawa 2014.

McDonough J., Egolf K., The Advertising Age Encyclopedia of Advertising, Routledge 2015.

Mohamad M., Ishihara S., The Voice of Asia: Two Leaders Discuss the Coming Century, Kodansha International, Tokyo New York London, 1995.

Ruszkowski J., Ponadnarodowość w systemie politycznym Unii Europejskiej, Wolters Kluwer, Warszawa 2010.

Nihon Bankoku Hakurankai Kyōkai, Japan World Exposition, Osaka, 1970, Japan Association for the 1970 World Exposition, 1969.

http://psz.pl/117-polityka/percepcja-unii-europejskiej-w-japonii

http://isap.sejm.gov.pl/DetailsServlet?id=WDU20051120938

http://oide.sejm.gov.pl/oide/images/files/dokumenty/traktaty/Traktat_amsterdamski_PL_16.pdf

https://polskawue.gov.pl/files/polska_w_ue/prawo/traktaty/Traktat_amsterdamski.pdf

http://www.consilium.europa.eu/pl/meetings/international-summit/2015/05/29/

http://europa.eu/rapid/press-release IP-15-5069 en.htm

http:/www.mg.gov.pl/Wspolpraca+z+zagranica/Wspolpraca+gospodarcza+Polski+z+krajami+wsc hodnimi $+\mathrm{i}+$ pozaeuropejskimi/Japonia.htm

http://www.iitrade.ac.in/kmarticle.php?topic=EU\%20and\%20Japan $\% 20$ to\%20start $\% 20$ FTA $\% 20$ talks

http://www.sony-europe.com/article/id/1178278971660

http://www.klimatech.biz.pl/wp-content/uploads/2012/02/Daikin-Systemy-Klimatyzacyjne-2011.pdf http:/www.hitachi.eu/en/about/hitachi/

www.jetro.go.jp/poland/linki/firmy.html

http://www.mg.gov.pl/Wspolpraca+z+zagranica/Wspolpraca+gospodarcza+Polski+z+krajami+wsc hodnimi $+\mathrm{i}+$ pozaeuropejskimi/Japonia.htm

http://trade.ec.europa.eu/doclib/docs/2006/september/tradoc_113403.pdf

http://www.msz.gov.pl/pl/polityka_zagraniczna/inne_kontynenty/azja_i_pacyfik/stosunki_dwustronne_azja_pacyfik/japonia?printMode=truemsz.gov.pl/resource/feec $2 \mathrm{fc} 6$ -b64d-4a16-8104-020f23765052:JCR

http://rudlinconsulting.com/top-30-japanese-companies-in-europe/

\section{Streszczenie}

W artykule przedstawiono główne determinanty wyboru lokalizacji japońskich firm w Unii Europejskiej, ze szczególnym uwzględnieniem firm Polsce. Zaprezentowano historię stosunków między dwoma partnerami handlowymi. Podczas wyboru lokalizacji w UE Japończycy biorą pod 
uwagę czynniki takie jak: dostępność i jakość zasobów ludzkich, potencjał rynkowy, rzeczywiste koszty nieruchomości, infrastruktura i sieć, a zwłaszcza koncentrację przemysłu. Dostępność wykwalifikowanych pracowników pracujących w dziedzinie nauki i technologii jest również jednym z głównych czynników wyboru lokalizacji przez japońskie firmy. Japońskie firmy inwestujące w projekty produkcyjne aktywnie wykorzystują korzyści z jednolitego rynku europejskiego.

Słowa kluczowe: Unia Europejska, Japonia, Polska, firma, rozwój gospodarczy

Numer klasyfikacji JEL: F23, F53 